\title{
BONIFACE OKAFOR: THE NIGERIAN SURREALIST PAINTER
}

\author{
Okechukwu Nwafor* \\ http://dx.doi.org/10.4314/og.v9i1.9
}

\section{Abstract}

Very little has been written on Surrealism in Nigerian art. While I may not trace any historical origin of this practice in Nigeria, I will concentrate on the art of one singular individual - Boniface Okafor. In this essay, therefore, I approach Surrealism from its Western origin and then take on the art of Okafor as a veritable exemplar of his Western counterparts. I show that Okafor, a former member of the Aka group of exhibiting artists, was a strong artist who reveled in the esoteric. His art resonates with critical thematic and formalistic attributes that provide cue for understanding some hidden aspects of human existence. Basing my essay on the Nigerian environment, I show that as a mystic artist, he may have been misunderstood for his strong attachment to his art and world views. I also hint at the fact that most of his works are often bifurcated along the lines of religion and mystery.

\section{Surrealism}

The term surrealism was coined in 1917 when the poet Guillaume Apollinaire described the style of the ballet parade, for which Picasso had painted the sets as "... a sort of Surrealism in which I see a point of departure for a series of manifestations which transform art..." It was an art movement that grew out of Dada and which like Dada was not seen as a style but as a way of life. Surrealists were fascinated by the theories of Sigmund Freud who, from his base in Vienna, influenced the whole world with his revolutionary ideas in psychoanalysis. One of the most famous of all 
Nwafor: Boniface Okafor: The Nigerian Surrealist Painter

Surrealist works is Salvador Dali's The Persistence of Memory (1931), (Figure 1), a small painting that many people simply call 'the mixed watches.' In this work a scorched, corroded landscape is inhabited by a weird, fetal-type creature and several bendy watches - an indication of time not only halted but dissolving away. Perhaps in this work Dali's fantasy, his hallucination is to conquer once and for all over time.

Surrealism assumed a volta face of art of this period and as such heralded a world of new artistic experience. Surrealism sought to explore, among other things, the world of psychic experience, the conscious and the subconscious and reposition man as a supernatural being in the social order. The chief inspiration of surrealism is the amalgamation of sundry disparate realities as could be found in the whimsical world of dreams. Accidental compositions and perhaps writings are employed to evoke reactions that may well relate to a spectator's subconscious experience.

\section{On Dream Imageries}

Dream is a state or an experience of the unconscious mind. It is when the world of reality becomes completely enveloped by images, thoughts and feelings of the non-conscious mind. It is a state of fantasy when the mind escapes into some fanciful, unlikely situations. 'Modem' art was, however, the major initiator of this type of art with derivatives from abstract art. Mark Getlein observes that the Surrealists "appreciated the logic of dreams, the mystery of the unconscious, and the lure of the bizarre, the irrational, the incongruous, and the marvelous" (153). In dream art, many cosmic entities provide a panorama. There is sometimes, the romance of heaven and hell, the living and the dead, the good and evil. Examples are the metaphors of Joan Miro or Yves Tanguy; the melted clock dream of Salvador Dali and bird dream images of Max Ernst. 
Ogirisi: a new journal of African studies vol 92012

Commenting on dream art, Paul Waldo Schwartz states that the image is truly kaleidoscopic, the one God sometimes becomes four; the dead are sometimes restored to life; the corners belong to no discernible plane of space (10). In this type of art, subjectivity plays a principal role as Schwartz further concludes that the dreams themselves offer a number of clues; they begin to suggest in their imagery a kind of psychic map of the territory in which the poet-magician (artist) navigates his course (10). Helen Gardner presents yet another subjective view of dream art:

In painting dream images, the artist is handicapped by the fact that each dream is the experience of a single individual and depends for its meaning on the events in the private life of that one person; the clearer and more detailed its description, the less likely that it will be comprehensible to others (832).

From the above it becomes clear that dream art almost undoubtedly presents experiences so personal that correspondence with an audience of any dimension becomes difficult if not impossible except when the artist, through his preference of familiar symbols, describes experiences common to all groups of people.

\section{Locating Boniface Okafor in Dream Art}

Boniface Chukwudum Okafor was born on March 16, 1950 in Numan, located in the old Gongola state and now in the present Adamawa State of Nigeria. He was educated at St. Patrick's Catholic Primary School, Numan from 1954 to 1961. From 1962 to 1966 he attended Villanova Secondary School, Numan.

The dream art of Boniface Okafor may not emerge as a surprise to those who may have known his antecedents. This is 
Nwafor: Boniface Okafor: The Nigerian Surrealist Painter

because Okafor studied philosophy in Bigard Memorial Seminary Enugu from 1969 to 1973. One can, therefore, conclude that Okafor's art may have been shaped by his philosophical understanding of life. This foundation again may have informed his re-definition of art beyond mere physical, corporeal knowledge to discernment in the esoteric.

Perhaps philosophy as a discipline provides one with a subjective reasoning and interpretation of life as noted by Ralph Waldo Emerson: "Philosophy is the account which the human mind gives to itself of the constitution of the world ... The mind is urged to ask for one cause of many effects; then for the cause of that; and again the cause, diving still into the profound..." Having dived successfully into the profound world of philosophy with a BA in Philosophy from Bigard, Okafor went to the Institute of Management and Technology (IMT) Enugu where he translated his profound knowledge into visual experience. He studied at IMT from 1975 to 1979 and bagged a distinction in graphic Art (HND IMT, 1979). This was the point when Okafor started a visual journey into the psychic world of surrealistic art. Upon graduation, he had undertaken different careers including teaching but none had succeeded without a commensurate indulgence in the art of painting.

Okafor began as a graphic artist but later saw painting as a better instrument of expression, hence the need for a combination. Today, Okafor was well known as a painter than a graphic artist despite an attempt at merging both.

\section{Okafor and the Cosmic}

The works of Boniface Okafor reveal formal inventiveness that is cosmic as well as astral. In all his paintings the word 'cosmic' is revealed metaphysically and mystically. It is important to note that his artistic maturity became manifest almost the period he joined the Aka group of exhibiting artists 
Ogirisi: a new journal of African studies vol 92012

in 1986. With a consistent participation in this group's annual exhibition, until its demise in 2000, Okafor was a visible ambassador of a new group of surrealist artists to emerge in Nigeria in the old and new millennia.

Most times, his paintings have beginnings and no end. Perhaps they are as Epicurus, the philosopher said "... infinite, for the finite has an extremity which can only be observed against something else, which is impossible in the case of the universe."

His paintings are an aftermath of his thought processes, which have crystallized into a personal philosophy over the years. His paintings are not part of the uniform mass thoughts that have conventionalized formalism and themes in the Nigerian art scene, rather they are consequences of his mental capacity evolving with mystery, magic and myth.

In terms of productive output, Okafor excelled as observed by Chike Aniakor

By 1981, Boniface Okafor had Dream of the Barren Maid, The Maid of Honour, and Power Spot, the first two in oil and the last in drypoint. Others are Apparition in the third quarter of the Moon, Mysterious Mother, By the lakeside for 1990, Profile of a Generation, Face of Reality and Invocation I, all in oil. 1994 and for 1996, Royalty, His Are the Time and The Ages and Oracle and many others"(3).

Aniakor's outline serves to open vista for an appreciation of Okafor's oeuvres which, no doubt may not be summarily encapsulated in a single treatise as this. It also reflects Okafor's sense of thematic captioning which are replete with strong psychic undertones. Spirit of Earth, (1987), figure 2, is an example of Okafor's determination to continue inventing new ways to experience dream, to feel it, and to keep finding 
Nwafor: Boniface Okafor: The Nigerian Surrealist Painter

expression for the impossible predicament of animal forms amid a cosmic vastness. Spirit of Earth may be Okafor's own interpretation of the Igbo earth spirit which Parrinder summarizes thus:

The Earth 'spirit' Ala is the most important public and private divinity of the Igbo of Nigeria. It is more important than any of the sky gods. Ala is often seen in the wooden and clay images in which the Igbo delight; with a child. On her knees and sometimes a crescent moon near her she has been compared to the Egyptian Isis with Horus, or even with some Italian Madonnas" (49).

Contrary to the above idea of the earth spirit or goddess, Okafor's own spirit is a silent world possessed by an exotic image of half snake, half wooden female form beside a perfectly round reddish moon. No doubt, this creature is mysterious and does not augur well with the conception of the modern Igbo Christianity where $\operatorname{satan}^{1}$ can take the most improbable form in the spiritual world. Okafor seems to infuriate the modern Igbo religious dogma where such creatures have been consigned to the eternal lake of fire under the new Christian dispensation. Among the Christian faithfuls 'goddess' is despicable and attracts as much condemnation as the artist or anyone who extols it. One may then ask, "why then does Okafor revel in the rendition of such abhorrent and detestable concept of 'goddess' or 'spirit.' The answer lies in the artist's seeming resolve to seek freedom regardless of the influence of popular thinking in the Nigerian Christendom.

Okafor may not have nurtured any nihilism towards the religious dogmatism of the period, yet his art tended towards a latent and explicit spiritual determinism. Being a member of Rosicrucian Order, he had tried to play on the naive experiences of non-members through works that suggest levels 
Ogirisi: a new journal of African studies vol 92012 of esoteric attainment. Nothing stops at placing this artist within the bounds of public misconception because of his perceived deviation from artistic norm. The Third and The Fourth Steps (Figure 3) shows a ladder, springing from an undefined space on the upper side of a human head. Beside the ladder are four square shapes encompassing a human lip, nose, ear and eyes - the four sensitive parts of the human head. Other entities embodied in the work include an animal figure, some rose-like creatures and a nameless figure with two prominent aberrant eye- balls and a hole and star sign. The medium of this work is dry point. If one speculates on the possible motive behind this work, what springs to mind is Okafor's quest for the top most hierarchy of the mystic milieu.

During his lifetime, Okafor almost seemed to assume a taciturn personality while engaging in his art. This attitude may not be unconnected with the propensity of the general public to segregate any member of the mystic society; a practice common among modern Christianity in Nigeria where AMORC and other mystic societies are openly blasphemed and vociferously condemned during Christian crusades.

One noticeable feature about The Third and The fourth Steps is the brooding darkness that pervades the entire work, building up an inclination of a further dismal and obscure journey towards space.

One recurring principle of the surrealist artists of history is their creation of a poignant allegory of empty space in which objects seem to float or hang precariously on end. For example, in Marc Chagall's Crucifixion, there is a free, floating composition of human figures with unexpected juxtapositions of the tangible and the bizarre and in Salvador Dali's The Persistence of Memory, an immense sea of space unfolds a landscape without perspective, drifting to perpetuity, while in Giorgio De Chirico's The Delights of a Poet, there is a 
Nwafor: Boniface Okafor: The Nigerian Surrealist Painter

visually unsettling tendency reinforced by sharp proclivity of space and shadow.

More than any art historical epoch, surrealism has provided the spectators with a viewing capacity that transcends the ordinary; often compelling a non-observant spectator to question and interrogate obvious impossible and impracticable situations. This is a situation calling for self-contradictory enquiry of the esoteric essence of existence by an impassioned on-looker who must be prompted to apply improvisation to fathom the unfathomable.

Fantastic as this practice may be, one is completely frightened by the chimerical evolvements of this art which Okafor himself has obscured the more through a portrayal of the mysteries of death. Something Died Here (Figure 4) seems to appall an observer to sudden experience of human adventure through an indifferent death even as it fails to provide an avenue for possible resolution of the abstruse imageries within. The basic recognizable human figures suggest a clash between the living and the dead. The figure with a candle perhaps remains as stupefied as the spectators. No doubt, the scene bespeaks of fright, horror or panic especially when the lying human form presents an odd and aberrant placement of the legs which indeed mystifies the vision of the bare-buttocks. Okafor's ingenuity in the surrealist practice could stand tall among even his Western contemporaries and he did not deter from the principal style of the Surrealist movement. Essentially, it is important to note that some traits found in surrealism was also noticed in some other movements like the Art Deco but one distinguishing feature remains 'seriousness'. Edward Lucie - Smith had noted that "Surrealism was an art movement which always took itself very seriously, even in the hands of Salvador Dali" (43). It would be understandable therefore, why Okafor's subjects abhors frivolous narratives but rather dwells on the grave, 
Ogirisi: a new journal of African studies vol 92012 demure and often sober aspects of existence. No less seriousness is attached to the theme, To Be Titled in 1992 (Figure 5) than any other politically motivated paintings of Nigeria in the 1990s.

This work which takes us into the political developments of Nigeria in the 1990s is reminiscent of the inglorious military junta of Ibrahim Babangida and his deceptive tricks with the democratic transition. In August 1985, Mohamadu Buhari's regime was deposed in a peaceful military coup, led by Major General Ibrahim Babangida, an army chief of staff at the time. The Armed Forces Ruling Council (AFRC) under the leadership of Babangida and the support of his chief of army staff, Major General Sani Abacha (who later became a Nigerian president) ruled the country from 1985 to 1993. Under his regime, Babangida promised to restore democracy. However, despite initial indications of the military's commitment to this goal, hopes for a swift transition began to fade by the end of the decade. The schedule was repeatedly revised and the government made increasingly intrusive attempts to "manage" the process of political party formation. Apart from efforts to restore the country back to constitutional rule, the Babangida regime also had to deal with issues of corruption, declining economy under the Structural Adjustment Programme (SAP) and violent clashes between Christians and Muslims on the issue of the imposition of the Sharia law. It also had to suppress the attempted overthrow of the regime. In the hope of restoring the country back to civilian rule, the AFRC created two new political parties: the National Republican Convention (NRC) led by Bashir Tofa from northern Nigeria and the Social Democratic Party (SDP) led by Chief Kashimawo Olawale Moshood Abiola, from the southwest, both, wealthy businessmen. The imposition provoked wide spread criticism. The SDP, led by the late Chief Moshood Abiola, obtained majority votes in the June 121993 
Nwafor: Boniface Okafor: The Nigerian Surrealist Painter

presidential elections. Nevertheless, Nigerian's hopes for a return to civilian rule were dashed when the military regime of General Ibrahim Babangida annulled the results of the national elections after votes were counted.

Okafor, having produced this work in 1989, might have heralded these unfortunate political developments of the 1990's and as such, in his ever clairvoyant mysticism, predicted the political upheavals that was to alter the history of Nigerian for years to come. In this work the emphasis is on a human hand emerging from the ground with outstretched fingers pointing upwards and enclosing three images. The images (perhaps emblematic of leaders) shows a uniformed man, a figure in pharaoh-like costume and another image which looks like the image of an ancient Egyptian queen. That Okafor expected to title the work by 1992 showed that he had a premonition, and in fact presented his prognosis, of the cancellation of June 121993 elections and the eventual crisis that followed. The characteristic of this work is a great facility in draughtsmanship, a fine sense of composition and great sensitiveness to the aesthetic relations of forms to each other. This work tends towards psychological expressionism such that Okafor expressed rather his own emotions about the characteristics of the then military dictatorship, their badness and callousness. The highly expressive character of the hand is not subordinated by any dark cloud rather by emphasizing the criticality of the outstretched fingers one undertakes a deeper inquiry into the underlying message of the enclosed images. The enclosed images arranged in order of a military uniformed man, a Pharaoh and a queen may suggest an optimism nursed by Nigerians of an eventual transition from military to a democratic state.

The last of Okafor's work I want to dwell on is Mammy Wata (Figure 6). Okafor, employs a nondescript composition here to obfuscate our idea of Mami Wata. In this work the 
Ogirisi: a new journal of African studies vol 92012 white figure beside a man who stretches out a hand (holding a staff) may be the Mami Wata. And the aura of Okafor's Mami Wata overwhelms with a whirlwind which throws their heads and some parts of their body into abstruse concealment.

Mami Wata's journey into Africa is a long and historic one. In most African societies, the existence of aquatic spirits ably represented through symbolic religious and artistic images were instrumental to the flourishing of "newer water divinities, such as Mami Wata." (Henry John Drewal, 28). For example, carved images of water spirits are seen among the Mende and Sherbro in Sierra Leone and Liberia as Tingoi/Njaloi, in the Ijaw of Niger Delta region of Nigeria, in Igbile Society as headdress of Edo Kingdom of Benin in Nigeria, in the Agbala image of the Igbo of Eastern Nigeria.

A school of thought believes that Mami Wata's presence started creeping into the Africans' consciousness through the European explorers and Merchants who brought their replica of mermaid images. Henry John Drewal had noted that "a figurehead given in about 1910 to a Yoruba man who worked for a British trading company in Lagos was identified by its owners as Mami Wata" (38). Beyond other scattered evidences pointing to the influence of European objects on the African image of Mami Wata, the image of the Snake Charmer was another influential element to the Africa's Mami Wata image. Drewal had noted how the port of Hamburg played a major role in the spread of the image of Snake Charmer into Africa. He noted how the popularized image of "Maladamatjaute" (51-52) ${ }^{2}$ was to become a preponderant visuality that would linger eternally in Africa's image of Mami Wata. According to Drewal:

By 1901, about fifteen years after its appearance in Hamburg, the snake charmer image had already been interpreted as an African water spirit, translated into a three-dimensional carved image, 
Nwafor: Boniface Okafor: The Nigerian Surrealist Painter and incorporated into Niger River Delta water spirit headdress that was photographed by J.A. Green in the Delta town of Bonny (28).

An Igbo proverb says "Onyinye Mami wata bu wete isi bia were isi" which translates as "Mami Wata's gift is not without life threatening returns." This saying underscores a deep belief of the Igbos of South eastern Nigeria in the existence of the water deity called 'Mami Wata.' To some the popular visual image of Mami Wata is "the head and torso of a woman and the tail of a fish" while to others it could be a picture of an exceptionally beautiful woman. In Igbo land it is often used euphemistically by the later group to discuss a powerful, dangerous, spiritual water deity especially in folk tales.

'Mami Wata' attracts and scares. It is loved and at the same abhorred. To some it is alive while to others it is dead. A group sees it as an embodiment of good while another perceives it as symbol of viciousness, wickedness and imperfection. Indeed, in Africa, Mami Wata's image is saturated with complex interpretations that are as enigmatic as they are inexplicable. 'Mami Wata' started loosing its traditional significance after many years when human societies became gripped by the claws of Christianity and perhaps modernity. The new 'cosmopolitan' society with its culturally and ideologically heterogeneous groups gave birth to new generation of thinkers who have other interpretations to 'Mami Wata'. One can argue that to the new generation religion Mama Wata is the devil which must be hunted down; it is the incarnate of evil which must be cast into the abyss of fire. And to the elites, and intellectual group, it is simply superstition and myth. We may not be able to situate Okafor within any of the above groups but his is a response to the predominating image and conception of the Africans about Mami Wata. 
Ogirisi: a new journal of African studies vol 92012

Being a mystic affords him a leverage to anchor a personal artistic idiosyncrasy on such mythic imagery and creature. The work captures this very popular mindset which holds that some people offer supplication to Mami Wata from whom they acquire immense spiritual, economic and political power. These women dancing to the rhythm of an unknown sound may also represent the entire humanity that believe in, and worship, Mami Wata while the faint view of canoe paddlers seem to suggest yet another universe where Mami Wata wields special influence.

\section{The Death of the Artist}

For justice to be done to this paper, it would be apt to dwell, briefly, on the dangerous circumstances surrounding Okafor's demise.

The emergence of democracy in Nigeria on May 1999 ended 16 years of consecutive military rule. By the year 2000, Enugu, a cosmopolitan city in eastern Nigeria had played host to one of the greatest population of armed youths in Nigeria. These armed bandits were a direct result of arms proliferation otherwise occasioned by the political happenings of Nigeria in the wake of the transition from military to democratic government in 1999. Politicians desperate to win election in their constituencies had employed the services of the youths such that in the eventuality of a deadly political encounter between rival political opponents, these youths who were illegally armed, served as thugs who were used to rig elections. The politicians having secured their offices through the barrel of the guns failed to fulfill their promises to the youths. Having lost all hopes and confidence in the ruling politicians these disappointed youths absconded with their arms and became a menace to the society and their neighborhood. They engaged in armed robbery and other criminal acts which collectively 
Nwafor: Boniface Okafor: The Nigerian Surrealist Painter

made the leadership of the then government of Enugu State unpopular.

Assassination, murder, sporadic shootings and the likes were a common phenomenon and it would be befitting to say that 'security' in its ample connotation totally evaded the entire Enugu Landscape. It is, perhaps in response to this security situation that O'Femi Kolawole notes that "the issue of security of lives must not be relegated to the background ... otherwise, we'll continue to lose our best minds and rob our nation and its future the positive contributions of these late compatriots" (65). Kolawole however asks an unpleasant question: 'Is there any guarantee that a man who leaves his house hale and hearty in the morning would return home alive by the close of work?'

As though, Kolawole was aware of the incident leading to the death of Boniface Okafor, he provides us with a likely mental consciousness of a typical inhabitant of Enugu in the wake of the fourth republic politics in Nigeria. Boniface Okafor was, however one of such men referred to by Kolawole who left his residence but did not make it back home. Okafor was hit by a stray bullet from an armed robbery gang in Enugu on his way back to his residence after seeing off a colleague who had visited him. He died on the spot. This deviation surely suits this piece because of its ability to underscore the hard times that confronted life in the city of Enugu where Okafor spent greater part of his life as an artist. It was this hard time, brought about by the collapse of the security system of Enugu that snatched the life of Okafor.

\section{Conclusion}

In this essay I have brought Boniface Okafor to the fore, for a renewed appreciation of his art and his contributions to the Nigerian version of the Surrealist movement. In addition to a brief chronology of his antecedents as an artist, I undertook an 
Ogirisi: a new journal of African studies vol 92012 in-depth review of his few art works through which I discussed salient issues in the Nigerian society where Okafor lived and worked as an artist. This little piece may not be able to make the necessary impact needed to launch Okafor and his art into the proper historical space in the discourse of modern Nigerian art. However it will serve to open a medium for more comprehensive investigation into the artist's life and his art.

*Okechukwu Nwafor PhD is a Lecturer in the Department of Fine and Applied Arts, Nnamdi Azikiwe University, Awka.

\section{Notes}

1. Satan has become a complex entity in today's modern pentecostalism in Nigeria. Its character has been exaggerated and it is common to find people engaging in larger than life stories of how the devil transformed into mysterious creatures. And more worrisome is the tendency by modern day Christian converts to ascribe everything unusual (including in the visual arts) to satanic influence. Most worrisome is the satanisation of certain art forms making it almost impossible for the artist to attain certain freedom in his professional practice.

2. Drewal notes that Breitwiser had brought "Maladamatjaute from Southeast Asia and she began to perform as a snake charmer in Hagenbeck's production. Her fame as snake charmer soared as much as her image such that her image began to appear in Paris and the United States and later Africa. However in Africa it was manifested in a different context and imbued with a different meaning. 
Nwafor: Boniface Okafor: The Nigerian Surrealist Painter

\section{References}

Aniakor, Chike. AKA Exhibition Catalogue. 2000.

Bode, Carl and Malcom Cowley (eds), The Portable Emerson. New York: Penguin Books, 1981.

Drewal, Henry John. Mami Wata, Arts for Water Spirits in Africa and its Diasporas. Los Angeles: Fowler Museum, 2008.

Epicurus, (n d). "Thoughts of the Month." In Rosicrucian Digest. Unknown Publisher.

Getlein, Mark. Living with Art. New York: McGraw-Hill, 2002.

Helen Gardener, Art through the Ages. New York: Harcourt Brace Jovanovich, 1980.

Kolawole, O'Femi. "How Much Are Our Lives Worth". The Guardian, Thursday, April 52007.

Lucie - Smith, Edward. Art Deco Painting. London: Phaidon Press Limited. 1990.

Parrinder, E. G. African Traditional Religion. London: Sheldon Press. 1976.

Schwartz, Paul Waldo. Art and the Occult. London: George Allen and Unwin Ltd., 1977. 
Ogirisi: a new journal of African studies vol 92012

\section{List of Figures}

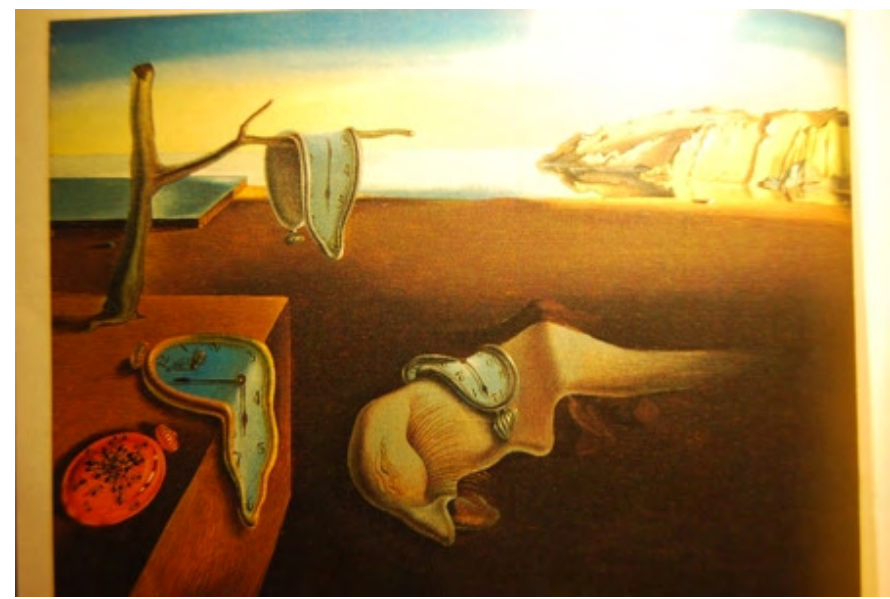

Figure 1. Salvador Dali. The Persistence of Memory. 1931. Oil on Canvas 9.5 x 13 inches The Museum of Modern Art, New York.

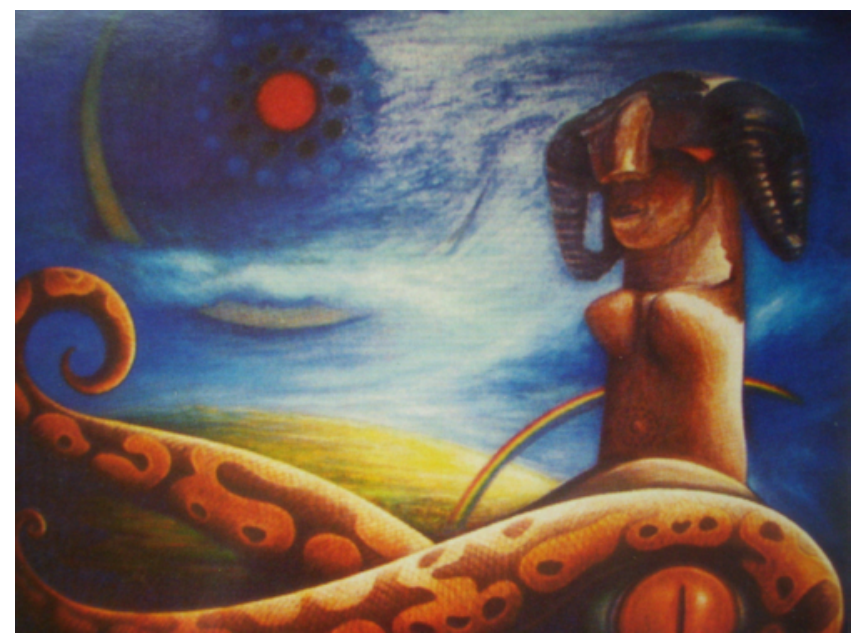

Figure 2. Boniface Okafor. Spirit of Earth. Oil, 36 x 36 inches, (1987). 
Nwafor: Boniface Okafor: The Nigerian Surrealist Painter

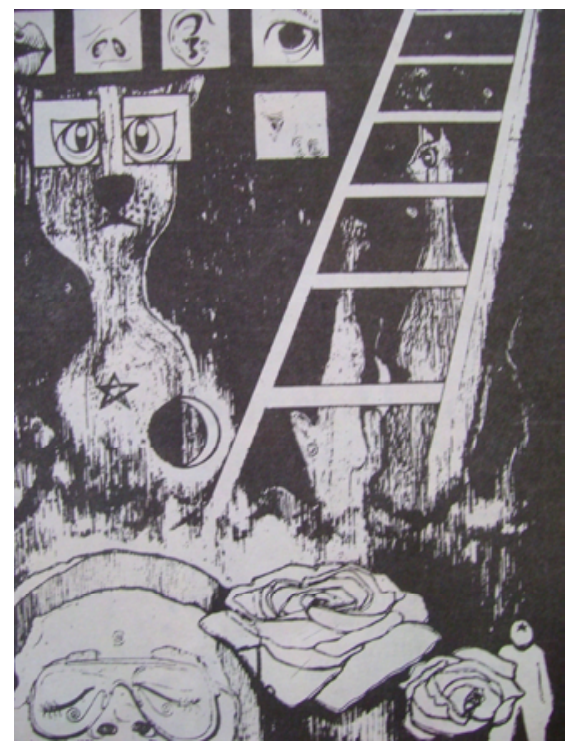

Figure 3.Boniface Okafor. The Third and The Fourth Steps. Oil, (1987).

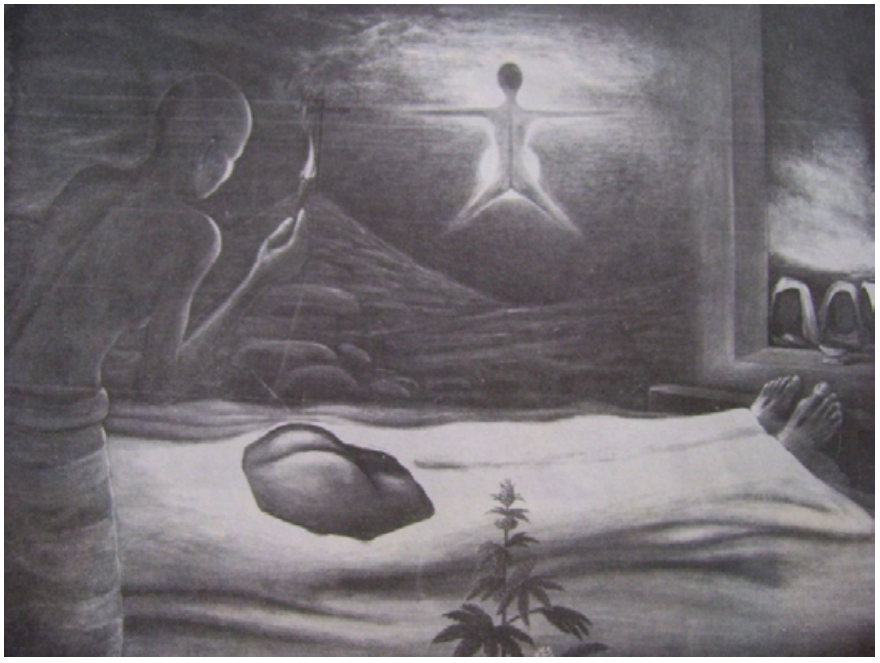

Figure 4. Boniface Okafor. Something Died Here. Oil, (1987). 
Ogirisi: a new journal of African studies vol 92012

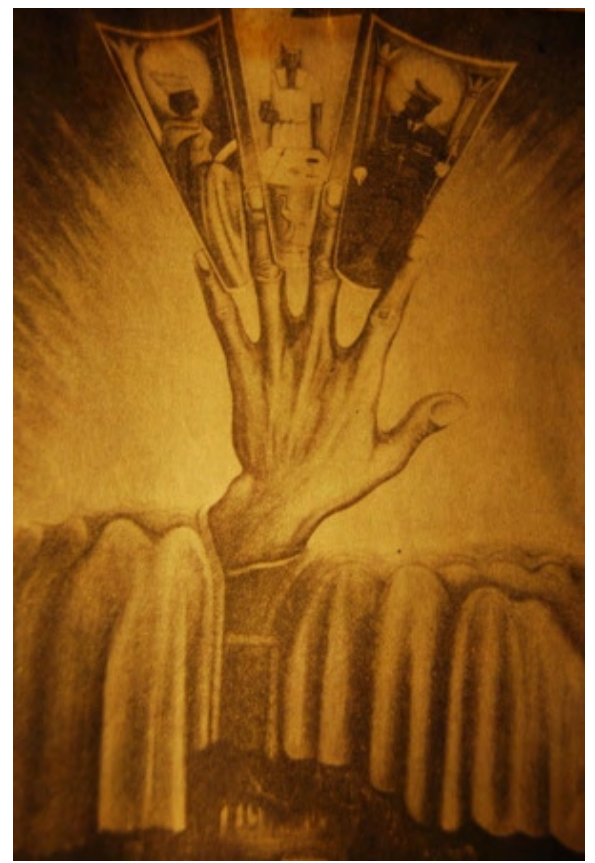

Figure 5. Boniface Okafor. To Be Titled in 1992 . Oil. $90 \mathrm{~cm} x$ $68.5 \mathrm{~cm} 1989$.

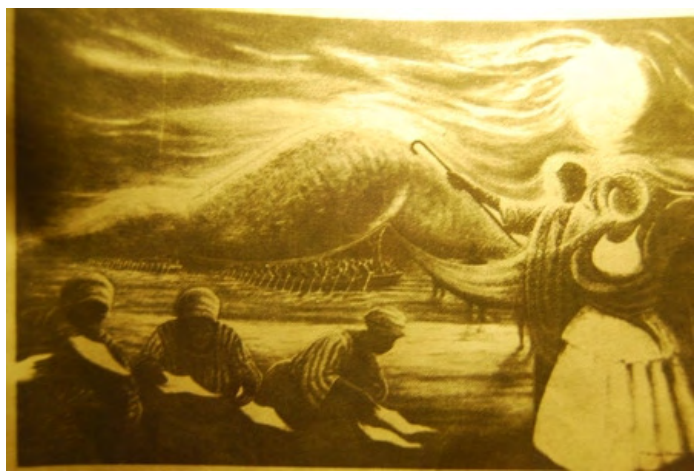

Figure 6. Boniface Okafor. Mammy Wata. Oil. (1986). 